\title{
Article
}

\section{The Pink Tank in the Room: The Role of Religious Considerations in the discussion of Women's Combat service - The Case of the Israel Defense Forces}

\begin{abstract}
Women serve in diverse roles in the $21^{\text {st }}$ century militaries of the world. They are no longer banned exclusively from combat. The presence of women on the battlefield has raised religious arguments and considerations. What role do religious arguments play in the discussion regarding women's military service? The current paper examines this question in the context of the Israel Defense Forces (IDF): a conscription-based military that conscripts both men and women, religious and secular, for both combat and non-combat postings. Using the case of the pilot program in the IDF attempting to integrate women in the Israeli tank corps, the paper argues that religious considerations serve the same purpose as functional considerations and can be amplified or lessened, as needed.
\end{abstract}

Keywords: military; IDF; female soldiers; religion and the military; religious considerations; religious women's conscription

In November 2016, the issue of integrating women in the IDF tank corps began to be discussed. The Israeli national-religious caricaturist Yossi Shachar published a caricature of a large pink tank, labeled "feminism" threatening a small tank with a frightened solider inside it labeled "the IDF" (Shachar, 2016). Shachar's caricatures are published routinely in the weekend Tora pamphlet of Shvi'i ${ }^{1}$ The caricature was a response to the IDF considering the integration of women in the tank corps. It describes a prevalent perspective in Israeli society: having women in combat is not in the IDF's interests and is really a feminist ploy. If women will begin to serve in combat, the IDF will become a weak force, unable to protect Israeli citizens. Feminists, according to this view, are willing to risk security in the name of equality.

Despite protests, including on the part of retired senior officers (Walla News, 2016), the IDF continued to discuss the option of women in the tank corps. In 2018 it began a pilot program seeking to explore this option. After running the program in 2018-2019, the pilot was completed and the IDF is currently (2020) assessing its results (Israel Supreme Court Cases 5923/19;34/20). The pilot program itself examined the possibility of having women in tank formations that would be stationed on borders, not maneuvering formations (which is usually the primary use of tank formations). This means that the pilot program examined not only a new type of personnel (women), but the option of a new type of formation that does not exist in the IDF. ${ }^{2}$

It is widely accepted that the reason the women who participated in the pilot program do not serve in the tank corps today and that no additional programs have begun, is due to religious considerations. Since many religious men serve in the tank corps in their own designated units, the IDF fears they will refuse to serve with women and balks at this possibility. The IDF has denied this is the reason women have yet to join the tank corps (Israel Supreme Court Cases 5923/19; 34/20). However, this incident, coming after a number of others, begs the question what role do religious considerations play in the relationship between women, militaries and religion?

\footnotetext{
${ }^{1}$ As was this caricature.

2 Which is curious in and of itself and raises the question why bother having a pilot program for a military role that doesn't exist?
} 
Integrating women in combat is not a new phenomenon, and it not an exclusively Israeli issue. It creates different types of concerns and generates arguments that support integration, as well as arguments against it. The arguments and concerns used to support or oppose women's service in combat can be grouped in two main categories: functional and religious.

While functional concerns are common to many militaries and can be understood universally, at least to a large extent, religious issues with women's combat service are more specific and culturebased. In this respect, when attempting to better understand the role religious concerns play in the discussion of women's combat service, using a conscription-based force allows for a better examination of this topic. In a conscription-baased force, the military is obligated to conscript all soldiers; including religious ones. An all-volunteer force (AVF) can avoid having religious individuals in its ranks (Removed for peer-review). For this reason, the current paper will focus on the Israel Defense Forces, a conscription-based military where both men and women serve, religion is a viable force, and women are allowed to serve in some combat positions. This is by no means an exhaustive case study, and hopefully in the future additional case studies will shed more light on this topic.

As noted, when discussing the issue of women serving in combat roles in the IDF, arguments tend to split into two main categories. Functional arguments address concerns regarding functionality and combat readiness: are women physically able to be combat-ready and not compromise the fighting force. Religious arguments address concerns such as: it is unsuitable for women to serve in combat from a religious perspective; will allowing women to serve in these positions potentially infringe upon the rights of religious male soldiers; what will the effect of mixedgender service be on morality among the troops.

While religious arguments are used mostly in the media and by religious figures, with no official support by military officials, combat-readiness arguments are used more often as the official military position, with the religious establishment willing to relate to these as well. Functional arguments are usually supported by academic, semi academic and medical evidence, and comparisons to other militaries. Religious arguments are usually based on a specific interpretation of religious law (halakha). At the same time, functional and religious arguments serve different purposes, but both are tools employed by those who support or oppose women's combat service. In this respect, there is no fundamental difference between both types of arguments.

The proposed paper will look at the Israeli case and map out the issues raised within the relationship between the IDF, women (religious and secular) who serve in the IDF in a variety of roles, religious male soldiers, and religious authorities asking: what role do religious arguments play in this dynamic?

\section{Categories of Arguments}

As noted, when discussing women's presence on the battlefield, two main categories of arguments usually surface (See Figure 1). These categories are not present in every military, but both exist in the IDF.

The first category includes functional issues concerning the effect female soldiers can have on battle-readiness: can a force that includes women be equal in battle to a force that is exclusively male? Do women impair the effectiveness of battle formations? Can they perhaps improve performance? If so - how?

Unpacking this category further, "effectiveness" includes both physical and mental abilities. When women serve alongside men, does their presence affect men psychologically? This can be a positive effect: causing them to try harder so as not to seem weaker than the women; restraining men and causing them to moderate their behavior, which is usually coarser in the military. It can also be a negative effect: affecting unit cohesiveness adversely; causing the men to be more protective of the women and therefore less aggressive in battle.

Additional sub-categories of effectiveness concern the women themselves: Can women meet physical and mental standards needed in battle? Do mixed-gender units perform well during maneuvers and under fire? 
Included in the category of functional issues is the topic of prisoners of war (POWs). Are female prisoners of war "worth" more than male POWs? Will a country be obligated to "pay" more for their release? How will they be (mis)treated by the enemy? How will this affect their fellow POWs and the civilian population of the country they represent?

Unit cohesiveness can be considered a sub-topic of functionality. It can be broken down further into sub-concerns. Can a military unit achieve true cohesiveness when it includes more than one gender? What are the risks of sexual assault in mixed-gender units and are they greater than in maleonly units? Are women soldiers more likely to fear their own unit members more than the enemy?

These are questions every military seeking to include women in combat positions must contend with. Consequently, there is no shortage of scholarship - military and academic - exploring these questions (such as: Carreiras, 2006; Holm, 1993; Solaro, 2006; Mackenzie, 2015; King, 2013, Epstein and Heled, 2014; Sagi, 2014; Wiener and Tevet-Wiesel, 2014; Ben-Shalom and Turgeman, 2018). These questions are also debated in the Israeli public sphere, as well as within the IDF itself.

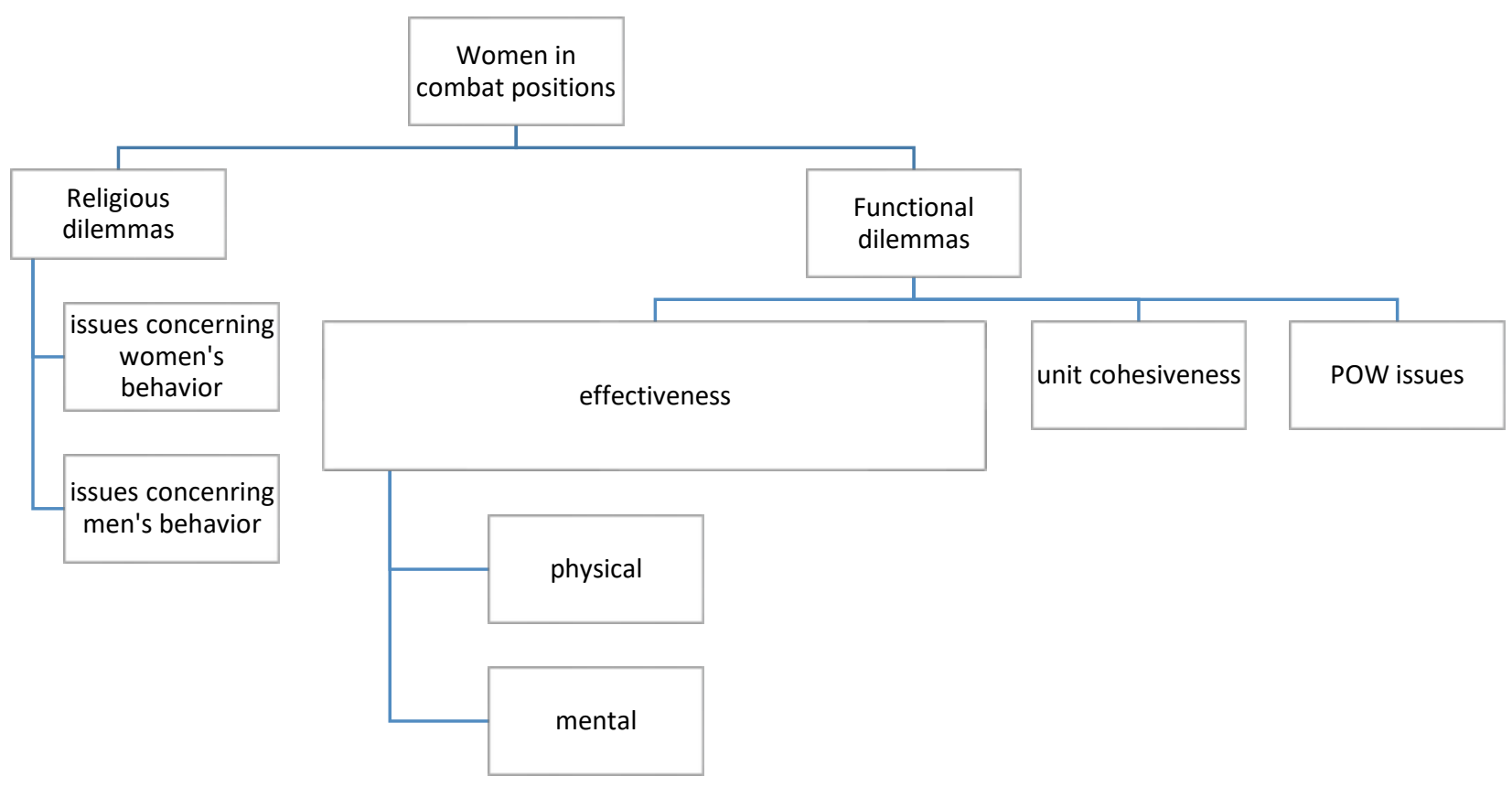

Figure 1. Main Categories of Arguments.

The second category includes concerns relating to the religious dimension of women's military service. This category has two main sub-categories of issues: the effect of military service on the women themselves; and the effect on the men serving alongside them.

Religions, certainly Abrahamic religions, generally frown on the presence of women on the battlefield. According to this narrative, a woman's place is at home, raising children, and not in the frontlines, taking lives. Women are tasked with "giving life" and nurturing. It is therefore wrong to cause them to be in the unnatural situation of doing the exact opposite. Consequently, a woman in uniform is perceived as immodest, and different religions frame her presence differently. Since the current paper focuses on Israel, we will focus on the religious dimension as framed by Orthodox Judaism.

The halakhic discourse regarding women's presence on the battlefield begins with Maimonides. ${ }^{3}$ While Maimonides stated clearly that in the context of Obligatory War (milchemet mitzva) women are obligated to join the fighting force (if not as part of the actual fighting necessarily) (Laws of Kings and

${ }^{3}$ For a comprehensive explanation of the halakhic background regarding military service as seen through the halakhic prism, as well as women's military service, see: (Removed for peer-review). 
their Wars, 5), later commentators tried to minimize their presence in battle (for further discussion see: Min HaHar, 1983; Shaviv, 1983, Y. Cohen, 1993).

In $20^{\text {th }}$ century Israel, when the need for Jewish women in battle became obvious, rabbinic figures became vocal concerning female soldiers during the debate concerning conscription (1949). In this context, the main halakhic concerns included the concept that serving in a military is "conduct unbecoming" a proper Jewish woman (kol kvuda bat melech pnima). Additionally, it was seen as immodest to have women in an all-male environment such as a military base. Wearing a uniform (specifically wearing trousers) and bearing arms - both defined as masculine garb - were likewise seen as immodest. A woman should not be given commands from strange men outside her own family (her father or husband). Moreover, women's characters are ill-suited for battle. Women are easily frightened and lack sufficient courage to perform well in the field. While none of these points are actual religious edicts, in current interpretation of halakha, they were accepted as facts, thereby turning "soft", interpretational edicts, into "hard" undebatable ones. They do tie in to the functional arguments mentioned above concerning physical and psychological limitations women have in battle (Removed for peer-review).

Accordingly, this sub-strand of religious arguments focuses on the women themselves: women should not serve in any military, and certainly not be on the actual battlefield. It is debatable whether or not they may serve in supportive roles, but they should certainly not bear arms. Women who do serve, place themselves in immodest environments and are endangering themselves, their reputation, and their morality.

Furthermore, their presence in battle is detrimental to the troops. Not only is this because, as noted above, women are easily frightened and will demoralize the troops. God frowns upon a military force that does not enforce separation of the sexes so that the fighting force remains morally sound. A military where women serve, will undoubtedly become morally corrupt and will not be awarded victory by God. Therefore, if a woman chooses to serve of her own accord, she should be banned from service so that her presence does not cause God to favor the opponent (Shaviv, 1983; Min-HaHar, 1983).

It is important to note that this category of dilemmas does not differentiate between religious and secular women. Looking through the religious prism, all women - regardless of their religious observance - should be banned from the military.

The second sub-strand in this category concerns the effect on male soldiers in a mixed-gender force. Clearly, the religious perspective is that men are easily morally corrupted by the presence of women in the field. They can also be demoralized, as mentioned above. The focus of this sub-strand is the men: men in general should not have unsupervised contact with women. Certainly not with unmarried women. God-fearing men, not just soldiers, should not be put in situations where they are alone with women. More than it being an immodest situation, it causes men to find themselves in complex halakhic circumstances and religious authorities do not feel men can be trusted to behave properly when they are alone with a woman.

The religious basis for these rules is more substantial, certainly in Orthodox Judaism. While not all religious men abide by the rules set for the separation of the sexes (yichud), it is harder to argue that they are based on "soft" halakhic grounds. These rules have further implications concerning the exact type of interaction between women and men: is it permissible for a woman to speak in public before a male audience? For example, may a woman serve as a tank instructor? May a woman sing in public at a military event? ${ }^{4}$

Whereas functional concerns can see the issue of women in combat as a cost-benefit issue and note advantages as well as disadvantages, religious concerns do not see women's combat service as containing any positive aspects. It is always undesirable and the focus is on how to manage the situation if it arises. As will be demonstrated below, those who utilize religious dilemmas when questioning women's combat service, can also employ functional dilemmas in their reasoning. Those

${ }^{4}$ For a description of the issue of women's presence in the public sphere in the IDF, the issue of yichud and women's singing in public, see: A. Cohen and Susser, 2014. 
who utilize primarily functional dilemmas, seldom turn to religious dilemmas. Interestingly, while religious and secular male soldiers play an important part in the considerations of those arguing for and against women's combat service, religious women are excluded from the conversation. When discussing women in combat, "women" are considered a monolithic category.

With these points in mind, we can now turn to the way these dilemmas are utilized in the discussion concerning women's military service in the IDF.

\section{The Use of Functional and Religious Arguments Currently in Israel}

The issue of mixed service has drawn much media attention and public discussion in Israel. The Segev Commission (2007) attempted to draft IDF official policy concerning women's service for the $21^{\text {st }}$ century. The Segev Report discusses the functional concerns in depth. It devotes some space to the issue of "the proper integration" (hashiluv haraui), which refers to IDF policy regarding separation on the sexes in order to allow religious soldiers to feel comfortable in mixed-gender settings. For example, it maps out how living quarters will be organized, what clothing can and cannot be worn in public (specifically sports attire), and so on. The Segev Report (2007) upholds the Proper Integration, stressing it benefits all soldiers in that it creates an atmosphere where both men and women's privacy needs are upheld.

At the same time, the Report does not voice any religious concerns. Even when listing the reservations of the Military Rabbinate's delegate to the Commission (R. Eyal Karim, Appendix 5, Segev Report, 2007), these are framed as functional ones: it will be impossible to uphold The Proper Integration in the field - reality does not allow for separation; Women are not all physically able to serve in all positions.

Despite taking care to frame all concerns in functional terms, the issue of religion is explicitly expressed once. Karim noted that joint service on a military naval vessel and in the same closed vehicle "goes against halakha" (p. 97). In other words, the actual citing of halakha as the reason the Rabbinate's delegate opposed the Commission's conclusions, appears unambiguously just this time. Other reservations are not framed as halakhic concerns, but as functional ones.

This tendency continued throughout the next decade. When the military itself discussed women serving in combat, it framed its concerns in exclusively functional terms. ${ }^{5}$ This, of course, is understandable. What is somewhat surprising, is that the IDF does not refer in any way to the rights of religious soldiers. In other words, the IDF is careful to refrain from juxtaposing women's service with religious rights of any kind. What women can and cannot do in the IDF is always presented in functional terms by the IDF. The military is careful not to portray gender equality as the flip-side of religious rights.

Likewise, in the latest episode concerning women in combat positions, that of the tank crew pilot program mentioned above, the framing of the issue is entirely in functional terms. The State's response to the Supreme Court Case regarding the IDF discontinuing its pilot program for female tank crews (Supreme Court Cases 5923/19; 34/20) has no reference to religious concerns. The State (representing the IDF) refers to the women's physical abilities and to their ability to function as members of a tank crew. Likewise, no mention of difficulties on the part of religious male soldiers can be found.

Semi-academic writing, such as articles in the right-wing Mida online magazine and in Maarachot, the periodical published by the IDF, also take care to focus on functional arguments. For example, Raz Sagi, a retired colonel who serves as the head of the IDF Fortitude Forum, who has published and speaks extensively on the topic of women in combat, argues in an article in Maarachot against women in combat. All of his arguments are functional, and do not refer to the issue of the

\footnotetext{
5 This can be seen - among other cases - in the State's response to the Alive Miller petition the Supreme Court, regarding women's service as pilots, see: Alice Miller vs. The Minister of Defense and others, 4541/94.
} 
rights of religious soldiers (Sagi, 2014). ${ }^{6}$ Likewise, an article in Mida directly addressing the issue of women in tank crews, focuses exclusively on functional concerns, mainly the medical aspect of combat service and on its effect on women's physical well-being (Greenstein, 2016).

During the aforementioned discussion of women in tank crews, two high ranking officers in the reserves who served in the tank corps, opposed women's service in tank crews publicly. Brig.-Gen. (res.) Avigdor Kehalani cited the trauma of war as unsuitable for women (women are mentally unsuited for battle) and likewise pointed out that "a woman's role is to be a mother and to bear children" (Walla News, 2016). Maj.-Gen. (res.) Yiftach Ron-Tal likewise focused on functional concerns and highlighted the fact that no other militaries in the world integrate women in combat postings in the tank corps.

These articles, and others like them, highlight two important points. First, in general those who oppose women's combat service in public and were also the most vocal in connection with the female tank crew pilot program, tend to hold conservative views in general, not just concerning women in combat. For the most part they are old-school military veterans, many times senior officers in the reserves. Their conservative views are not limited to integrating women in the ranks, but include opposition to what they see as "leftist" tendencies, such as disobeying orders in the ranks in connection with political issues (sarvanut). They also tend to hold more right-wing political views. They are not religious and therefore it would be odd for them to employ religious terminology. Consequently, their arguments are based firmly on functional concerns. However, the undertones are sometimes more general, such as Kehalani's aforementioned view on women's role in society.

Second, those who oppose the stationing of women in combat frame themselves as champions of women's health and well-being. They are opposing combat service because it is detrimental to the women themselves: women in combat suffer from more march fractures than men, they are in danger of uterine prolapse, as well as other medical conditions, women shouldn't be in battle for their own good and for the good of the country, and so on. In other words, they are opposed to women's combat service because they care about women.

On the other hand, the religious establishment tends to use both functional and religious considerations when discussing the issue. Past halakhic writings addressing women's military service (in general, not combat postings) have always cited halakhic considerations, naturally. Classic cases include articles by R. Shlomo Min-HaHar (1983) and R. Yehuda Shaviv (1983) who admit that the basis for excluding women from the battlefield is social convention. However, in this case, social conventions are strong enough a basis and can be seen as halakhically binding. The main religious classic arguments address women's military service in general, not creating a separate category for combat service. As noted earlier, these focus on the fact that serving in a military in any capacity is "conduct unbecoming" a proper Jewish woman, in the broad sense of the concept. ${ }^{7}$ The halakhic aspect, in its most basic form, sees women's service as an unnatural situation for women. Women's service also has detrimental effects on the men in the fighting force. In this respect, the classic halakhic arguments do not use functional terms but are purely religious. Again, they make no distinction between combat and non-combat posts (Removed for peer-review).

In the past decade, the main religious voice against women's combat service comes from rabbis who serve in pivotal roles in pre-service preparatory seminaries (mechinot), as well as the more stringent rabbinic voice coming from Hesder yeshivot closer to the view points of yeshivot hakav (the religious seminaries stemming from the Mercaz HaRav yeshiva, founded by R. Avraham Yitzchak HaCohen Kook). These figures have inspired a campaign against women's service in general and women in combat in particular. While the current paper cannot cover all of the writings and public statements of these rabbis, a number of recent examples can be presented in order to demonstrate the most pivotal important points highlighted here.

${ }^{6}$ It is interesting to note that Sagi is a popular speaker, invited to speak on this topic at religious pre-military preparatory seminaries (mechinot). In general, it seems that those opposed to women's service in combat join forces frequently.

7 Removed for peer-review. 
In 2017, Hotam, ${ }^{8}$ a rabbinic organization aimed at integrating religious outlooks in state matters, published a short film on youtube portraying military service as seriously harming the young religious women who choose to enlist (Hotam, 2017). The film focuses on the women themselves and uses socio-religious reasons to explain why military service is harmful for religious women: while they think they will be doing the state a great service by enlisting, in truth the system is only using them to portray itself as pluralistic, it does not understand religious constraints, does not address real concerns religious women in uniform have, forces them to go against their religious beliefs, ${ }^{9}$ and in general causes the women to be less religious and less feminine. Religious women would do better to serve in national civilian service. Interestingly, Hotam has an entire section of its activities dedicated to the issue of convincing religious women to avoid enlistment. In continues to publish short films and other material on social media to this effect.

In a pamphlet published by Hotam (Ben David, no date) to encourage women to avoid enlistment, the main arguments can be grouped in two categories. First, military service is not a place for religious women. It is a liberal-feminist ploy to cause religious women to become secular. Second, in general, feminists are left-wing and wish to harm the IDF and cause it to be unfit for combat and this is why they push for integrating women in the ranks. Women in general are not needed in the military. Consequently, feminine postings are ridiculous and superfluous and do not contribute to security. The military is not a place for women, no matter how convinced the women are that they are doing a good deed. In truth, they are harming themselves and the IDF when they serve - even in non-combat postings (Ben David, n.d.). In other words, the pamphlet includes both religious and functional arguments.

Another pamphlet published at the same time included short articles by heads of yeshivot and mechinot published by LIBA, ${ }^{10}$ addressing the integration of women in combat. While the articles focus on religious arguments (women should not be in uniform, their roles lie elsewhere; forcing religious male soldiers to serve with women, goes against their right to serve in single-gender units), they also employ functional arguments (the IDF lowers physical standards so that women can meet them; women hamper the units they join and harm their ability to fight effectively; mixed-gender units are not as professional as male-only units) (LIBA, n.d). This pamphlet consolidates both functional and religious arguments, speaking to both religious men and women, and utilizing the entire range of possible arguments against women's combat service in order to present its case.

Another medium attacking women's service, are sectoral media publications, mainly the weekend paper BeSheva and pamphlets given out at synagogues every weekend, supposedly dealing with the weekly tora portion (dapei parashat shavua), but in truth serve as sectoral newspapers. The pamphlets include responsa on various issues, articles by religious figures and news that interests the national-religious sector. One of the topics that features regularly is how religious soldiers fare in the IDF. Among the topics that surface are the way secular officers treat religious soldiers, levels of kashrut, the banning of beards, and - naturally - mixed-gender service. In these cases, the pamphlets usually focus on the religious male soldiers and on what is seen as a violation of their rights to serve according to their beliefs. For example, in January 2020, the pamphlet Shvi'i covered a complaint by reserve soldiers in the artillery corps who recounted how they were expected to camp in the field with female soldiers. This was seen as disregarding their religious convictions. The soldiers said "we

${ }^{8}$ Hotam site: https://www.chotam.org.il/\%D7\%A2\%D7\%9C-\%D7\%A1\%D7\%93\%D7\%A8-

\%D7\%94\%D7\%99\%D7\%95\%D7\%9D/\%D7\%92\%D7\%99\%D7\%95\%D7\%A1-

\%D7\%91\%D7\%A0\%D7\%95\%D7\%AA-\%D7\%93\%D7\%AA\%D7\%99\%D7\%95\%D7\%AA-

$\% \mathrm{D} 7 \%$ C $\% \mathrm{D} 7 \% \mathrm{~A} 6 \% \mathrm{D} 7 \% 91 \% \mathrm{D} 7 \% 90 /$

${ }^{9}$ In the film, the religious girl who enlists with much motivation is forced to stand for guard duty alone with a man, cannot finish her prayer after meals, and little by little abandons her principles.

${ }^{10}$ Libayehudit.org - the organization presents itself as aiming at "strengthening the Jewish identity of the State of Israel" stressing the halakhic side of Judaism and attempting to demonstrate how it is relevant to the current lives of Israelis. 
asked and asked [not to train with female soldiers] and nothing helped [...] this can't be a military for secular soldiers only, this is the army of the People of Israel. We don't want change and for anything new to happen [to accommodate us], just for them to leave things the way they were until this last training session" (Shvi'i, 24 January, 2020, p.12). in this piece, as well as the follow-up item published a month later (Shvi'i, 28 Feb. 2020, p.14), the article stresses that serving together with women in the field (specifically sleeping in the same camp in the field) goes against religious beliefs and disregards religious soldiers' rights to serve according to these beliefs. This example mirrors the general tone of articles covering similar cases. All of these publications indicate just how disturbing women's military service is for religious figures from the more stringent end of the national-religious continuum.

In stressing how important it is that women stay away from military service, the religious establishment is signaling not only externally, but internally. Women cannot serve in uniform at all, and women who serve in combat are even more damaging to the IDF and the nation in general. It may be that since these religious voices fear they have lost the battle over women's military service in their own camp, since religious women do enlist, ${ }^{11}$ they are taking a last stand regarding combat service for women, and prepared to attack religious female soldiers so as to make sure that the final line of combat service will never be crossed.

In this respect, the issue of women in combat indicates that the conflict within Religious Zionism over religious women's military service has spilled over into the general sphere of the IDF: in an attempt to control women's conscription, the issue of women in combat is playing an internal role. By seeming to discuss a broader topic, rabbis can stress the detrimental side of women's military service and discourage religious women from enlisting.

Interestingly, while the discussion focuses on combat service for women, it pays no real functional attention to women serving in non-combat positions. All of the arguments against women's service in non-combat roles do not try to hint that women are unfit to serve in these postings. Likewise, there is almost no attention paid to men serving in non-combat positions and on their relationship with the women they serve with.

Religious concerns are very much present in non-combat situations, but rabbis do not voice them. To the best of my knowledge, only one rabbinic text addresses the halakhic difficulties faced by non-combat religious soldiers (Weinberger and Bitner, 2007) versus the very many responsa concerning combat soldiers. In the 500 plus pages of this book, one section alone deals with service alongside women and attempts to help soldiers deal with possible halakhically problematic situations. The five short chapters in this section do their best to help non-combat soldiers and assuage their conscience. There is certainly no attempt to convince them to find a different posting, where they will have no contact with women.

After understanding who uses which arguments in addressing women's combat service, we can now examine the way religious male soldiers themselves view the issue of women's military service and women in combat. This will put the official positions in better context and enable us to better understand the role religious argument play in this dynamic.

\section{Religious Concerns in Practice}

When using religious concerns to oppose women's service, are rabbis serving as spokespersons for religious soldiers? Are they indeed voicing difficulties from the field? Cohen and Susser (2014) have noted that usually, when rabbis and others stress that women in combat will infringe upon the rights of religious male soldiers, they are giving voice to the extreme point of view, not the mainstream.

In order to examine this point more in depth, this paper collected data from a focus group of 14 male soldiers toward the end of their service. All members of the focus group studied in religious high schools, all but one were still religious. Two did a year of national service before conscription.

11 The scope of the current paper does not allow for an in-depth discussion of this phenomenon. (Removed for Peer-Review) 
One enlisted at the end of highschool. One studied in a preparatory religious seminary (mechina). The rest (ten soldiers) studied in yeshivot (9 in the hesder program, one in the shiluv program). Not all of the soldiers from the hesder program serving in designated single-gender units.

Of the 14 members of the focus group, nine were combat soldiers, four served in intelligence positions (all studied previously in a yeshiva) and one served in a combat support position. Four soldiers served in the paratroopers (in general units, not hesder units. Two in its reconnaissance units), two in the NAHAL brigade (in hesder units) and one in Givati (non-hesder unit). Two were tank crew members (one was a tank commander), both in the hesder program. Of the combat soldiers, one was an officer and one was in an officer training course. The soldiers serving in intelligence, as noted, all studied in a yeshiva before service (as opposed to a mechina). All served alongside women to various degrees.

The data from the focus group revealed some interesting findings. First, there was a marked difference between combat and non-combat soldiers, with non-combat soldiers serving alongside women in non-gender-segregated units. Consequently, most of the focus group members met very few women during their service. The combat soldiers met female instructors and administrators. They were usually not impressed with the professional level of the women. It seems that medical instructors were the exception to the rule, being more professional than tank, shooting and other technical instructors. One of the members of the focus group was a combat medic, who was impressed by the professional level of the women instructors he met during his training.

Combat soldiers preferred that their commanders teach skills over female instructors who were not an integral part of their team. Combat soldiers felt that while the female instructors knew the material, they were unaware of what happened in the field. Commanders were able to integrate hands-on experience when they taught various technical aspects and this was seen as more effective.

On the other hand, female instructors were well-liked by the soldiers. They welcomed the possibility to learn from someone who was not part of their regular chain of command and

...the reason I liked being near the [female] instructors was because they were - for a change nice and smiled. On the second day of basic training, which was definitely the worst day of my life, we had shooting instruction with Anat. Half an hour of humanity in the midst of black days with horrible commanders. I won't forget her ever..." (Amir, tank crew member, hesder student). ${ }^{12}$

"Girls are much nicer to be with [...] especially when considering combat soldiers, who are much more "gorillas" [behemot] and see fewer girls [during service and in general are disgusting]." (Ron, combat soldier, paratroopers, hesder soldier).

Ron felt that the soldiers he served with (mostly secular) were vulgar and he felt that it was better for him mentally to be around female instructors.

Asked specifically about their feelings concerning integrating women in the tank corps, the tank crewmembers didn't feel there was a real reason to ban women from tank crews, if they were able to meet professional standards. Specifically, loaded the cannon quickly. They noted that there was no minimum weight and height standard for male tank crew members beyond qualifications for combat service (whereas women needed to meet minimum requirements for weight and height in the pilot tank crew program). Some discussion was devoted to a crewmember (who was not in the focus group) who was relatively short $(1.55 \mathrm{~m})$ and a bad loader, but a good crewmember.

Most of the members of the focus group felt that in general in the IDF, the main problem with mixed-gender units was these units received poor quality manpower. All of the combat soldiers served alongside mixed units (Karakal or Bardelas) at various stages of their service. They felt both the men and women who were assigned to these units were unprofessional and found it hard to trust them in combat situations. They were unsure if this was a result of the fact the unit was mixed-gender or because these units did not receive "good" soldiers relatively to other infantry units (paratroopers and NAHAL in their case).

12 All name used here are pseudonyms. 
Combat soldiers also noted that in general, from their experience, when members of their units came in contact with women (generally instructors), the men behaved badly for the most part. This was mainly due to the fact that most men did not serve with women and did not know how to act around them.

The soldiers who served in intelligence came into closer contact with women. In general, they observed that their service was "more like a job in everyday life" where men and women worked together. Accordingly, they did find themselves working alone with women and sometimes found this uncomfortable. As noted, all of these soldiers in the focus group studied in yeshivot before their service. They recounted that their rabbis did not truly address the fact that they were going to serve together with women. When the issue was discussed, it was very superficially and in passing. However, one of them noted:

There were certainly situations [my] rabbis said it is better to be with the girls [than with secular men]. For example, in the mess if the boys are talking about girls and the girls aren't [discussing men, I should prefer to sit with the girls]. (Dan, non-combat, intelligence, hesder student)

In other words, Dan's rabbis felt the women were a better influence and that sitting with them, would help Dan avoid religiously-problematic situations (in this case: speaking about immodest topics, or even just hearing profanity when sitting with the men). Other members of the focus group could not recall any of their rabbis addressing the issue of mixed service in non-combat postings directly.

Naturally, further data is needed and future studies should be conducted with a broad range of soldiers in order to understand the issue in depth. However, for the current paper, these findings are helpful and stress that for the most part, the religious soldiers did not have strong feelings about women in combat - either for or against. They felt that gender-mixed units were unprofessional, but did not connect this directly to the fact women served there but to the make-up of the units themselves. Non-combat soldiers were inclined to view their service with women in context: at times joint service made them uncomfortable, but serving with secular men was also uncomfortable many times.

\section{Discussion}

It seems that presently in the field, very few combat soldiers, religious and secular, serve in close proximity to women. The current objections voiced by rabbis regarding women in combat are therefore not based on actual experiences, but speculation and on the fear of what such a reality might cause in the future. The difficulties joint service raises are both functional and religious, with the functional concerns being far more acute. The religious concerns are ones that connect to modesty (in the religious sense) and feelings about personal space and privacy: women and men serving together in the field cannot always find way to maintain privacy. Religious concerns also include the maintaining of physical distance between men and women. In the field, reality will not allow for these restrictions to be maintained.

On the other hand, at this very moment, most non-combat soldiers do serve with women and have done so for decades. This is not a theoretical or proposed situation. In the IDF non-combat postings include many mixed-gender positions, with intelligence postings requiring the most professional contact with women: religious soldiers who serve in intelligence positions will most certainly serve alongside women, often keeping long hours together in closed rooms. They will have long night shifts together, sometimes being the only man in the room with another woman. In halakhic terms, such service might even be more problematic than being in the same armored personnel carrier or Hummer, with many other crew members, in more intense situations where there is little time for small talk and thoughts.

As noted, religious male soldiers serve in these positions and their rabbis know this. This begs the question, why are the same religious concerns voiced reading combat not heard regarding noncombat postings. Perhaps this is due to the small numbers of the pre-military program students who serve in non-combat postings. Of the approximately 2600 students who enlist every year through 
these programs (mechinot and yeshivot hesder), about $20 \%$ serve in non-combat postings. ${ }^{13}$ Perhaps the small number of students who serve in non-combat positions is not enough to generate rabbinic attention. However, this seems to be an unfair conclusion: are not even these small numbers worthy of halakhic consideration?

Another possible explanation is that non-combat service is not as intense as combat service. Men and women need not share bathrooms when they serve in an office or on an organized base. They do not sleep in close proximity and physical distance can be maintained. However, as noted, desk jobs provide much more close personal contact than combat does. The laws of yichud certainly apply much more to non-combat situations. Therefore it seems that one must search for additional explanations to this phenomenon.

Another explanation might be that the religious establishment is just not aware of the halakhic difficulties non-combat mixed gender service poses. This may be true for some rabbis, but certainly not for all. It seems that many rabbis are very much aware of the issues at hand, but prefer not to discuss them.

An additional explanation is that the pre-service programs fear that if they try to negotiate with the IDF over single-sex service for their male students in prestigious postings (such as intelligence), they might lose the possibility of sending their students to "good" military jobs. The IDF might prefer to keep the women in these postings and move the religious male soldiers to less prestigious military jobs. It would be possible for the IDF to decide that single-sex service will be limited to certain military jobs, such as the military rabbinate, but that other postings require mixed-gender service. In this case, many young men might prefer to leave their pre-service religious program in order to serve in more prestigious roles. If this explanation if correct, the pre-service programs understand that while they are able to influence IDF policy regarding combat, their influence might be severely limited in noncombat issues. They therefore prefer not to create a problem where there isn't one and accept that their students will be in halakhically compromised situations. Since these students are a minority, and most students serve in combat roles, perhaps this is a sacrifice the programs are willing to make. They may try to prepare their students for such postings and be sympathetic, but they realize that they cannot forbid them from serving in non-combat mixed gender units.

If this is so, it seems that religious arguments - like all arguments - can be used at different times for different things. Like in other situations, the religious establishment prefers to pick its battles, concentrating of those that can be won.

This conclusion can be better understood when viewed together with the way the religious establishment views religious female soldiers. As noted in previous scholarship (Removed for peerreview), religious female soldiers are slowly gaining legitimacy. While in the past, religious women who enlisted were frowned upon and paid a social price when making this choice, it has become far more accepted for religious women to serve in uniform. While the religious establishment still opposes women's military service and does so publicly, in many ways it seems to have accepted the shift from below; realizing this is not a battle that can be won. Public rhetoric is decidedly against religious women's service in the IDF, as noted above, but in practice, no real social penalties are used against women who serve. Forcing those opposing women's military service to revert to the pamphlets described above.

It seems that for most religious leaders, the reason to oppose women in combat is internal. For some (though certainly not all) religious soldiers, serving with women is unfathomable because they have grown up with no contact at all with women who are not immediate family members. While this can be seen as a cultural issue, and not religious, some of the soldiers themselves view it as a fundamental halakhic consideration. A portion of these individuals do not meet girls in school or even in kindergarten. They do not go to mixed youth movements. Meeting women in the military will be the first time they encounter women in any situation, and they are unable to cope with this interaction. True, once they are discharged, even most of this group will study at universities or

${ }^{13}$ Author's interview with Leizer (Eliezer) Deutsch, deputy director of the Hesder yeshivot association (Igud yeshivot haHesder), 23 December, 2010. 
colleges where they will meet women. Some of them will work in positions where they will meet and work with women. But at that point in their lives, they will be older and married and the circumstances of working and studying alongside women will be different (or so their social group will think). It will not be the same as meeting and working with women when they are 19-20 and have never spoken to a girl in their lives. ${ }^{14}$ Serving in the IDF, a secular institution very far removed from their civilian lives, is difficult enough for these men without adding the possibility of serving with women. While most religious-Zionist men are not in this position, some are. For most of their rabbis, the main goal is to enable their students to get through military service in one piece religiously, and to enable them to return to their civilian lives and continue to be a part of their original communities. Most of these men serve in combat positions. Their leadership wants to minimize complications and therefore prefers to keep women out of the equation.

The other reason to oppose women in the IDF in general and in combat in particular is to deter religious women from enlisting. Here the religious voices hope that when seeing how opposed the mainstream (or what is perceived as the mainstream) is to women's service, religious women will think twice about enlisting. If they do enlist, they will certainly draw the line at combat postings in order to maintain some legitimacy. While some of these considerations may not be conscious ones, they seem to lie at the root of the issue at hand.

\section{Conclusion}

Religious justifications and arguments serve the same purpose as other justifications: they are a tool. As both King (2013) and Epstein and Heled (2014) note, the issue of women's military service, specifically in combat, is first and foremost a political and social issue. More often than not, those who oppose women's service in combat, do so due to social considerations and prejudices (HarelShalev and Daphna-Tekoa, 2019: 74). When weighing the issue of combat service for women, many considerations come into play. In this respect, religious considerations are no different. They play the same part functional considerations play; no more and no less.

At the same time, it is important to note that just as functional concerns are flexible and subject to socio-political influences, religious concerns are not as rigid as they sometimes seem. Religious men serve alongside women in non-combat postings. These can be no less problematic than combat postings when viewed in halakhic terms, and yet rabbis do not protest publically or try to force the military system to adapt itself to halakhic considerations in this case. Such behavior cannot be explained purely in halakhic terms. It seems safe to assume that the religious authorities are willing to negotiate at times, even if this comes at a halakhic cost. Realizing that they will not be able to influence all religious male soldiers to serve in "halakhically-safe" posts (i.e. without women) which are deemed less challenging, and that they would rather focus on the majority of their students (who serve in combat), they choose to avoid discussing the issue. Consequently, religious male soldiers can serve in intelligence postings, despite the halakhic difficulties.

In this respect, the answer to the question presented at the beginning of this paper regarding the role religious considerations play in the relationship between the IDF, the question of women in combat, and religious male and female soldiers, is rather mundane. Religious considerations can serve as a tool, to be used or not used, by the various actors in this relationship.

It seems that in the case of the IDF, religious considerations serve two main purposes. They are result of intra-religious tensions that spill over into the IDF, and they are a way to voice patriarchal views when framed as rights. This is not to say that religious soldiers do not find it difficult halakhically and culturally to serve with women. The reality of mixed-gender units is one that religious soldiers (both men and women) find truly problematic and solutions are needed, as long as the IDF remains a conscription-based force.

\section{References}

\footnotetext{
14 Again, this is not the majority of religious men, but a portion of this group is indeed very segregated when it comes to mixed-gender situations.
} 


\section{Israel Supreme Court Cases}

Or Abramson and others vs. The Minister of Defense and others 5923/19

Osnat Levy and others vs. The Minister of Defense and others 34/20

Alice Miller vs. the Minister of Defense and others, 4551/94

The Segev Commission Report, 2007

Ben David, Eyal (n.d.), Bat Chayil (n.p)

<https://www.chotam.org.il/\%D7\%97\%D7\%A0\%D7\%95\%D7\%AA/\%D7\%A1\%D7\%A4\%D7\%A8\%D7\%99\% D7\%9D-\%D7\%95\%D7\%97\%D7\%95\%D7\%91\%D7\%A8\%D7\%95\%D7\%AA\%D7\%91\%D7\%94\%D7\%95\%D7\%A6\%D7\%90\%D7\%AA\%D7\%97\%D7\%95\%D7\%AA\%D7\%9D/\%D7\%97\%D7\%95\%D7\%91\%D7\%A8\%D7\%AA-\%D7\%91\%D7\%AA\%D7\%97\%D7\%99\%D7\%9C/> accessed June 2020 [Hebrew].

Ben-Shalom, U., Lewin, E., \& Engel, S. (2019). Organizational processes and gender integration in operational military units: An Israel Defense Forces case study. Gender, Work E Organization, 26(9), 1289-1303.

Carreiras, Helena. 2006. Gender and the military: Women in the armed forces of western democracies. Routledge.

Cohen, Asher \& Susser, Bernard. (2014). Women Singing, Cadets Leaving. Civil-Military Relations in Israel, 12745.

Cohen, Stuart A. (1997). The scroll or the sword?: dilemmas of religion and military service in Israel. Taylor \& Francis. Cohen, Yehezkel. 1993. Women's Conscription and National Service: A Halakhic Inquiry, In Hebrew]. The Religious Kibbutz: Ne'emanei Torah Va'Avoda, $3^{\text {rd }}$ edition.

Epstein, Yoram and Heled, Yuval (2014). “Integrating Women in Combat: The Physiological Aspect," Maarchot 460 (2014), pp. 44-49 [Hebrew].

Greenstein, Arik (2016). “What you need to ask yourself before you get in a tank," Mida 22 Oct. 2016 < https://mida.org.il/2016/11/22/\%D7\%9E\%D7\%94-\%D7\%90\%D7\%AA\%D7\%97\%D7\%99\%D7\%99\%D7\%91\%D7\%AA-\%D7\%9C\%D7\%A9\%D7\%90\%D7\%95\%D7\%9C\%D7\%90\%D7\%AA-\%D7\%A2\%D7\%A6\%D7\%9E\%D7\%9A-\%D7\%9C\%D7\%A4\%D7\%A0\%D7\%99\%D7\%A9\%D7\%90\%D7\%AA-\%D7\%A0\%D7\%9B\%D7\%A0\%D7\%A1\%D7\%AA/>, accessed, April 2020 [Hebrew].

Greenwald, Hanan (2017). “They've made our girls crazy, they don't leave the army Jewish," NRG (7 March, 2017) < https://www.makorrishon.co.il/nrg/online/11/ART2/868/004.htmll, accessed: April 2020 [Hebrew].

Harel-Shalev, A., \& Daphna-Tekoah, S. (2019). Breaking the Binaries in Security Studies: A Gendered Analysis of Women in Combat. Oxford University Press.

Holm, J. (1992). Women in the military: An unfinished revolution. Gower Publishing Company, Limited.

Hotam (2017). “Film against Religious Women's Military Service," Hotam Youtube site (26 Jan. 2017), $<$ https://www.youtube.com/watch?v=heA1IpTNwwg >, accessed June 2020.

King, Anthony. C. (2013). The female soldier. Parameters, 43(2), 13.

LIBA (n.d.). BeElokim Na'aseh Chayil (n.p).

<https://libayehudit.org/\%d7\%90\%d7\%95\%d7\%94\%d7\%91\%d7\%99\%d7\%9d-\%d7\%90\%d7\%aa\%d7\%a6\%d7\%94\%d7\%9c-\%d7\%a2\%d7\%95\%d7\%a6\%d7\%a8\%d7\%99\%d7\%9d-\%d7\%90\%d7\%aa\%d7\%94\%d7\%a9\%d7\%99\%d7\%a8\%d7\%95\%d7\%aa-\%d7\%94\%d7\%9e\%d7\%a9\%d7\%95\%d7\%aa \%d7\%a3/>, accessed June 2020 [Hebrew]. 
Lomsky-Feder, E., \& Sasson-Levy, O. (2018). Women soldiers and citizenship in Israel: Gendered encounters with the state. Routledge.

MacKenzie, M. (2015). Beyond the band of brothers: The US military and the myth that women can't fight. Cambridge University Press.

Min HaHar, Rabbi Shlomo (1983). “Women in Obligatory War,” Tchumin 4:68-78 [Hebrew].

Sagi, Raz (2014). “Chalomot baAsfamia,” Maarachot, 457 (October, 2014), pp. 70-72.

Sasson-Levy, Orna (2010). “Where Will the Women Be? Gendered Implications of the Decline of Israel's Citizen Army," in: The New Citizen Armies: Israel's Armed Forces in Comparative Perspective (Stuart A. Cohen, ed.), (Routledge, 2010).

Shachar, Yossi (2016), “Former Land Command Head: Integrating Women in the Tank Corps will harm the IDF," Yossi Shachar's Facebook page <

https://www.facebook.com/shaharyosi/photos/a.132193503650036/627265990809449/?type=1\&theater $>20$

Nov. 2016.

Shaviv, Rabbi Yehuda (1994). “Women in Obligatory War,” [In Hebrew]. Tchumin 4:79-89.

Solaro, E. (2006). Women in the line of fire: What you should know about women in the military. Seal Press.

Walla News (2016), “Brig.-General (res.) Avigdor Kehalani, on Women in the Tank Corps: A Woman's Role is to Bear Children,” Walla News, 21 Nov. 2016 < https://news.walla.co.il/item/3015270>. Accessed: April 2020. 